\title{
PEMETAAN STATUS WILAYAH INSEMINASI BUATAN SUMATERA BARAT
}

\author{
Irzal Irda ${ }^{1}$, Toni Malvin ${ }^{1}$, Ulva Mohtar Lutfi ${ }^{1}$ dan Nilna ${ }^{2}$ \\ lProgram Studi Peternakan Jurusan Budidaya Tanaman Pangan \\ Politeknik Pertanian Negeri Payakumbuh \\ ${ }^{2}$ Dinas Peternakan dan Kesehatan Hewan Provinsi Sumatera \\ Barat \\ irzalirda@gmail.com
}

\begin{abstract}
ABSTRAK
Tujuan penelitian ini adalah untuk melihat batasan dan kriteria wilayah tahapan pelayanan IB (introduksi, pengembangan dan swadaya) di Sumatera Barat dengan batasan dan kriteria antara lain: jumlah pelayanan IB per tahun, Service per conception $(S / C)$ dan Conception Rate $(C R)$, waktu pelaksanaan IB, wilayah, jumlah akseptor, cakupan wilayah binaan, populasi akseptor, dan sumber dana. Penelitian ini dilaksanakan pada tahun 2014 di Kabupaten Limapuluh Kota, Kota Padang, Kabupaten Pasaman Barat, Kabupaten Agam, Kabupaten Solok dan Kabupaten Dharmasraya Sumatera Barat.

Berdasarkan batasan dan kriteria wilayah tahapan pelayanan IB, maka dapat disimpulkan bahwa Kabupaten Limapuluh Kota, Kabupaten Agam, Kabupaten Solok, Kabupaten Pasaman Barat, Kabupaten Dharmasraya dan Kota Padang masih berstatus Wilayah Tahap Pengembangan.
\end{abstract}

Kata Kunci : CR, Inseminasi Buatan, S/C, Sumatera Barat 


\section{PENDAHULUAN}

Keberhasilan perkawinan merupakan salah satu kunci sukses dalam rangka peningkatan populasi ternak sapi. Pada mulanya perkawinan ternak yang dikenal di Indonesia adalah kawin alam (KA), sekarang kawin alam masih merupakan pilihan dalam pengembangbiakan ternak terutama pada daerah yang belum dapat dilakukan inseminasi buatan. Pertimbangan peternak yang menjadi alasan penggunaan kawin alam antara lain: 1). Secara alamiah ternak memiliki kebebasan hidup di alam bebas sehingga dengan sikap alamiah ini perkembangbiakannya terjadi secara normal mendekati sempurna. 2). Secara alamiah ternak jantan mampu mengetahui ternak betina yang berahi, sehingga sedikit kemungkinan terjadinya keterlambatan perkawinan yang dapat merugikan dalam proses perbanyakan populasi. 3). Penanganan perkawinan alam memerlukan biaya sangat murah karena tidak banyak campur tangan manusia. 4). Metode kawin alam sangat efektif dan efisien digunakan pada pola usaha budidaya ternak baik secara semi intensif atau ekstensif serta pada pola integrasi sapi dengan tanaman perkebunan terutama sawit.

Peningkatan permintaan akan daging terutama daging sapi berakibat meningkatnya permintaan akan ternak jantan, 
mengingat ternak betina produktif dilarang untuk dipotong maka ketersediaan pejantan yang semakin berkurang akan mengganggu pelaksanaan proses kawin alam, disamping itu tidak dilakukannya rotasi pejantan dalam kawin alam menyebabkan terjadinya inbreeding sehingga akan terjadi penurunan mutu genetik dan tingkat produktivitas ternak.

Solusi yang dapat ditempuh untuk mencegah penurunan populasi, penurunan mutu genetik dan penurunan produktivitas ternak sapi adalah dengan melaksanakan program perkawinan melalui inseminasi buatan (IB) dan program tersebut telah dilaksanakan oleh pemerintah sejak tahun 1950. Di Sumatera Barat perkembangan IB pada ternak sapi juga semakin berkembang pesat seiring dengan perkembangan IB secara nasional, bahkan Embrio Transfer (ET) juga sudah banyak dilakukan dan menjadi suatu program rutin.

Pada tahun 2014 untuk mendukung percepatan pencapaian program swasembada daging sapi/kerbau dilakukan optimalisasi kelahiran dalam rangka meningkatkan populasi dan produksi sapi dan kerbau melalui kegiatan Optimalisasi IB dan Intensifikasi Kawin Alam (INKA). Untuk mendukung program tersebut telah dilakukan pengembangan kelembagaan IB dengan membentuk Satuan Pelayanan Inseminasi Buatan (SP-IB) mulai 
dari tingkat propinsi sampai ke daerah kabupaten/kota serta Pos IB sebagai unit terkecil dalam melaksanakan pelayanan, pencatatan dan pelaporan kegiatan IB di wilayah kerjanya.

Keberhasilan pelaksanaan IB sangat ditentukan oleh beberapa faktor, antara lain: genetik, pengetahuan atau pengalaman peternak, kualitas dan kauntitas semen, keterampilan inseminator, dan kesuburan ternak yang diinseminasi. Indikator keberhasilan pelaksanaan IB dapat diketahui dengan mengukur Service per conception (S/C) Conception Rate (CR) dan Calving Rate (Toelihere, 1981). Keberhasilan IB sebagai suatu program pemerintah dapat dilihat peningkatan fungsi kelembagaan IB dan tingkat partisipasi masyarakat dalam pengembangan IB yang dapat dilihat dari batasan dan kriteria wilayah tahapan pengembangan IB yang terdiri dari wilayah introduksi, wilayah pengembangan dan wilayah IB swadaya.

Berdasarkan hal tersebut diatas, maka dilakukan penelitian untuk mengetahui status wilayah pengembangan Inseminasi Buatan di Sumatera Barat, yang dapat dijadikan sebagai landasan untuk membuat kebijakan bagi pemerintah (Dinas peternakan dan Kesehatan Hewan) Sumatera Barat. 


\section{METODE PENELITIAN}

Penelitian ini berlangsung selama 8 (delapan) minggu, mulai tanggal 20 Oktober 2014 sampai tanggal 12 Desember 2014 yang dilaksanakan di Kabupaten Limapuluh Kota, Kabupaten Solok, Kabupaten Agam, Kabupaten Pasaman Barat, Kabupaten Dharmasraya dan Kota Padang, Sumatera Barat.

Penelitian ini menggunakan metode survei dengan melakukan pengamatan terhadap pelaksanaan IB di Sumatera Barat, pengamatan dilakukan pada 6 (enam) kabupaten/kota yang ditentukan berdasarkan populasi ternak sapi, jumlah akseptor, bangsa sapi yang dipelihara atau dikembangkan (lokal dan eksotis), ketinggian tempat dari permukaan laut, sehingga daerah yang diamati adalah Kabupaten Limapuluh Kota, Kabupaten Solok, Kabupaten Agam, Kabupaten Pasaman Barat, Kabupaten Dharmasraya dan Kota Padang.

Dalam penelitian ini diambil data primer berupa informasi yang diperoleh dari inseminator dan peternak (sistem sampling) melalui pengisian kuisioner dan data sekunder berupa laporan pelaksanaan inseminsi buatan dari inseminator yang sudah ada, laporan PKB dan laporan kelahiran ditingkat kabupaten/kota atau SP-IB II. Secara keseluruhan data yang dikumpulkan adalah jumlah pelayanan IB per tahun, Service per 
conception ( $S / C)$ dan Conception Rate $(C R)$, waktu pelaksanaan IB, wilayah, jumlah akseptor, cakupan wilayah binaan, populasi akseptor, dan sumber dana.

Berdasarkan data yang telah dikumpulkan, 6 (enam) kabupaten/kota dikelompokan berdasarkan batasan dan kriteria wilayah tahapan pelayanan IB seperti terlihat pada Tabel 1 berikut :

Tabel 1. Batasan dan kriteria wilayah tahapan pelayanan IB

\begin{tabular}{|c|c|c|c|}
\hline \multirow{2}{*}{ Uraian } & \multicolumn{3}{|c|}{ Tahapan Pelayanan IB } \\
\hline & Introduksi & Pengembangan & Swadaya \\
\hline \multicolumn{4}{|l|}{ Batasan } \\
\hline $\begin{array}{l}\text { - Jumlah Pelayanan } \\
\text { IB/tahun (dosis) }\end{array}$ & 300 & 600 & $>1000$ \\
\hline $\begin{array}{l}\text { - Service per Conception } \\
(\mathrm{S} / \mathrm{C})\end{array}$ & $>3$ & $2-3$ & $<2$ \\
\hline $\begin{array}{l}\text { - Conception Rate (CR) } \\
\text { Kritreria }\end{array}$ & 50 & 70 & 80 \\
\hline - Waktu pelaksanaan IB & $<5$ th & $5-10$ th & 10 th \\
\hline • Wilayah & SP-IB & SP-IB & SP-IB \\
\hline $\begin{array}{l}\text { - Jml. Akseptor } \\
\text { (ekor/th/inseminator) }\end{array}$ & $<100$ & $100-400$ & $>400$ \\
\hline $\begin{array}{l}\text { - Cakupan Wil. Binaan } \\
\text { (ekor/th) }\end{array}$ & 1.800 & 3.600 & 7.200 \\
\hline - Populasi Akseptor & $<10$ & 50 & 80 \\
\hline - Sumber dana & $100 \%$ APBN & APBN \& APBD & $\begin{array}{l}100 \% \\
\text { Peternak }\end{array}$ \\
\hline
\end{tabular}




\section{HASIL DAN PEMBAHASAN}

Berdasarkan hasil survei yang dilakukan, diperoleh data batasan dan kriteria wilayah tahapan pelayanan IB, yang dapat dilihat pada tabel 2 .

Tabel 2. Hasil analisis batasan dan kriteria wilayah tahapan pelayanan IB

\begin{tabular}{|c|c|c|c|c|c|c|}
\hline \multirow[b]{2}{*}{ Uraian } & \multicolumn{6}{|c|}{ Wilayah Tahapan Pelayanan IB } \\
\hline & 50 Kota & Agam & $\begin{array}{l}\text { Kab. } \\
\text { Solok }\end{array}$ & $\begin{array}{c}\text { Pasaman } \\
\text { Barat }\end{array}$ & $\begin{array}{c}\text { Dharma } \\
\text { s raya }\end{array}$ & Padang \\
\hline $\begin{array}{l}\text { Batasan } \\
\text { - Jumlah } \\
\text { Pelayanan } \\
\text { IB/Tahun } \\
\text { (Dosis) }\end{array}$ & 11.389 & 5.404 & 9.281 & 3.361 & 8.237 & 6.851 \\
\hline$\cdot \mathrm{S} / \mathrm{C}$ & 1,17 & 1,25 & 1,22 & 1,17 & 1,13 & 1,18 \\
\hline $\begin{array}{l}\text { - CR (\%) } \\
\text { Kriteria }\end{array}$ & 84 & 76 & 80 & 83 & 89 & 85 \\
\hline $\begin{array}{l}\text { - Waktu } \\
\text { Pelaksanaan IB }\end{array}$ & $>10$ & $>10$ & $>10$ & $>10$ & $>10$ & $>10$ \\
\hline - Wilayah & SP-IB & SP-IB & SP-IB & SP-IB & SP-IB & SP-IB \\
\hline $\begin{array}{l}\text { - Jumlah Akseptor } \\
\text { (ekor/ tahun/ } \\
\text { inseminator)* }\end{array}$ & 380 & 322 & 357 & 236 & 328 & 809 \\
\hline $\begin{array}{l}\text { - Cakupan } \\
\text { Wilayah Binaan } \\
\text { (ekor/tahun)** }\end{array}$ & 34.833 & 33.831 & 36.219 & 15.466 & 26.759 & 19.902 \\
\hline $\begin{array}{l}\text { Populasi } \\
\text { Akseptor } \\
\text { (ekor)*** }\end{array}$ & 9.502 & 4.832 & 7.968 & 3.063 & 7.225 & 5.660 \\
\hline $\begin{array}{l}\text { - Populasi } \\
\text { Akseptor (\%) }\end{array}$ & $27 \%$ & $14 \%$ & $22 \%$ & $20 \%$ & $27 \%$ & $28 \%$ \\
\hline - Sumber Dana & $\begin{array}{l}\text { APBN } \\
\text { APBD } \\
\text { Peternak }\end{array}$ & $\begin{array}{l}\text { APBN } \\
\text { APBD } \\
\text { Peternak }\end{array}$ & $\begin{array}{l}\text { APBN } \\
\text { APBD } \\
\text { Peternak }\end{array}$ & $\begin{array}{l}\text { APBN } \\
\text { APBD } \\
\text { Peternak }\end{array}$ & $\begin{array}{l}\text { APBN } \\
\text { APBD } \\
\text { Peternak }\end{array}$ & $\begin{array}{l}\text { APBN } \\
\text { APBD } \\
\text { Peternak }\end{array}$ \\
\hline
\end{tabular}


Keterangan:

* Diperoleh dari populasi akseptor dibagi inseminator aktif.

** Data diperoleh dari sumber di SP-IB dan Dinas terkait secara langsung.

*** Diperoleh dari rata-rata populasi akseptor per bulan (Januari - Oktober 2014) dikali 12 bulan.

\section{Service per Conception (S/C)}

Service Per Conception adalah jumlah pelayanan IB yang dipergunakan untuk memperoleh kebuntingan atau konsepsi pada kelompok akseptor IB (Susilawati, 2011). Semakin rendah S/C semakin tinggi kesuburan ternak betina tersebut, sebaliknya semakin tinggi S/C kesuburan seekor ternak semakin rendah (Partodiharjo, 1995). Ditambahkan oleh Rasad (2009) bahwa idealnya seekor sapi betina yang harus mengalami kebuntingan setelah melakukan IB 1-2 kali selama proses perkawinan.

Dalam suatu peternakan bila angka konsepsi berkisar 1,5 - 1,7 untuk setiap kebuntingan sudah dianggap baik (Partodiharjo, 1995). Berdasarkan hasil analisa data sekunder pada Kabupaten Limapuluh Kota, Kabupaten Agam, Kabupaten Dharmasraya, Kabupaten Solok dan Kota Padang, diperoleh kisaran Service per Conception (S/C) 1,13 - 1,25, dimana angka ini menunjukkan bahwa pelayanan IB di enam daerah ini sudah 
tergolong baik. Kelemahan dari data sekunder yang tersedia di enam daerah ini adalah tidak semua ternak sapi yang di IB juga dilakukan PKB, hal ini disebabkan tenaga PKB yang tersedia masih terbatas. Kabupaten Dharmasraya memiliki 23 orang tenaga IB diantaranya 16 orang $(69,5 \%)$ tenaga PKB. Kabupaten Solok memiliki 22 orang tenaga IB diantaranya 8 orang $(36,4 \%)$ tenaga PKB, Kabupaten Pasaman Barat memiliki 15 orang IB, diantaranya 11 orang $(73,3 \%)$ tenaga PKB. Idealnya setiap inseminator adalah tenaga PKB, seperti halnya Kota Padang yang seluruh tenaga inseminatornya sudah mengikuti pelatihan PKB yaitu 7 orang, walaupun demikian masih memiliki keterbatasan jumlah tenaga secara keseluruhan, seperti halnya dengan ULIB Bungus Teluk Kabung masih diisi oleh tenaga yang diperbantukan dari Pos IB Koto Tangah.

Kelemahan lain dari data S/C apabila dihitung dari laporan pelaksanaan IB oleh inseminator (bukan data PKB) adalah terjadinya perkawinan berulang dengan inseminator berbeda, apabila sapi tidak bunting pada IB pertama, ada kecenderungan peternak melaporkan sapinya berahi kepada inseminator lain, sehingga sapi yang sama di IB dua kali dengan inseminator yang berbeda dan kedua-duanya dicatat sebagai IB pertama padahal kenyataannya sapi tersebut sudah merupakan 
kawin berulang karena kegagalan IB sebelumnya. Hal ini merupakan suatu hal yang lumrah dan wajar bagi peternak mengingat peternak menginginkan sapinya bunting sesuai dengan pengorbanan yang sudah diberikannya.

Faktor yang mempengaruhi tinggi rendahnya nilai S/C diantaranya adalah faktor nutrisi dari pakan yang diberikan, ketepatan waktu pelaksanaan IB oleh inseminator dan kualitas straw yang digunakan. Berdasarkan hasil analisa data primer yang diperoleh dari kuisioner peternak, $75 \%$ peternak menerapkan sistem pemeliharaan ternak sapi dengan cara dikandangkan terus-menerus, sedangkan sisanya dengan cara dikandangkan pada malam hari dan digembalakan pada siang hari. Pakan yang diberikan berupa hijauan dan hasil limbah pertanian yaitu: rumput lapang, rumput gajah, jerami padi, dedak padi dan sangat sedikit sekali yang memberikan konsentrat campuran. Hasil analisa di atas menunjukkan bahwa kebutuhan nutrisi untuk ternak kurang terpenuhi, terutama untuk ternak yang dipelihara dengan cara dikandangkan terusmenerus. Hal ini sesuai dengan pendapat Susilawati (2011) bahwa kekurangan protein dalam ransum ternak betina dapat mengakibatkan berahi yang lemah, kawin berulang, kematian embrio dini dan aborsi embrio. 
Selain dari faktor nutrisi di atas, ketepatan waktu pelaksanaan IB juga menentukan keberhasilan kebuntingan, hal ini biasanya disebabkan karena peternak terlambat dalam mendeteksi terjadinya berahi atau terlambat dalam melaporkan terjadinya berahi kepada inseminator. Hasil survei yang dilakukan menunjukkan bahwa, secara teori rata-rata peternak sudah memiliki pengetahuan tentang tanda-tanda ternak sapi berahi. Namun demikian, tidak semua peternak yang mampu mendeteksi secara tepat. Kekeliruan peternak mendeteksi berahi disebabkan karena peternak belum hafal dengan tipe berahi sapi yang dipeliharanya dan juga karena sapi mengalami berahi tenang (silent heat) sehingga peternak tidak mengetahui kalau sapinya mengalami berahi, terutama untuk petani yang baru memiliki ternak. Dikman dkk. (2010) menyatakan bahwa dalam pengamatan berahi dalam induk sapi yang mengalami berahi biasanya diikuti dengan tanda-tanda sebagai berikut, yaitu: 1) Vulva terlihat bengkak, hangat, dan berwarna merah; 2) Keluar lendir dari vagina; 3) Gelisah (menaiki sapi lain atau kandang); 4) Keluar air mata; 5) Apabila dinaiki pejantan atau sapi lain akan diam; dan 6) Nafsu makan turun sehingga produksi turun sesaat. Untuk persentase kejadian berahi, $43 \%$ pada waktu 00.00-06.00 WIB, $22 \%$ pada waktu 06.00-12 WIB, $10 \%$ pada 
waktu 12.00-18.00 WIB, dan 25\% pada waktu 18.00-00.00 WIB.

Kualitas straw yang digunakan juga berperan dalam keberhasilan pelaksanaan IB. Straw yang digunakan di Kabupaten Limapuluh Kota, Kabupaten Agam, Kabupaten Solok, Kabupaten Pasaman Barat, Kabupaten Dharmasraya, dan Kota Padang adalah produksi dari BIB Tuah Sakato, BIB Lembang dan BIB Singosari. Hasil wawancara dengan beberapa peternak, kegagalan kebuntingan lebih sering terjadi pada perkawinan yang menggunakan straw yang diproduksi oleh BIB Tuah Sakato dibandingkan dengan straw yang diproduksi BIB Lembang dan BIB Singosari, namun hal ini tidak bisa dibuktikan dengan data mengingat tidak ada catatan yang khusus ditujukan untuk mengevaluasi kualitas straw yang digunakan.

\section{Conception Rate (CR)}

Conception Rate atau angka konsepsi adalah jumlah akseptor yang mengalami kebuntingan pada IB ke 1 dibagi jumlah semua akseptor kali 100\% (Susilawati, 2011). Angka kebuntingan didiagnosa dengan cara palpasi rektal dalam waktu 40-60 hari setelah dilakukan IB (Afiati dkk, 2013). Nilai CR ini mempunyai hubungan berbanding terbalik dengan nilai $\mathrm{S} / \mathrm{C}$, 
apabila terdapat nilai $\mathrm{CR}$ yang tinggi maka nilai $\mathrm{S} / \mathrm{C}$ akan rendah.

Hasil pengolahan data sekunder dari kelima kabupaten/kota menunjukkan angka CR berkisar 76\%-89\%, Menurut Soenarjo (1988), angka melahirkan 80\% sebagai hal yang sangat memuaskan dan perlu dipertahankan, pada umumnya untuk menemukan angka CR ditentukan oleh diagnosa kebuntingan secara klinis, yang memberikan hasil nyata dari sekitar 50 hari setelah dikawinkan dengan cara palpasi rektal atau cara-cara yang lain. Conception rate Kabupaten Agam masih dibawah 80\%, tetapi menurut Toelihere (1985), angka kebuntingan (CR) normalnya sekitar 70\%, sedangkan Direktorat Jenderal Peternakan (2010) memberikan pedoman dalam mengevaluasi keberhasilan pelaksanaan inseminasi buatan (IB) dengan memberikan nilai standar CR $62,5 \%$, service per conception (S/C) 1,6 dan calving interval (CI) 12 bulan.

Sama halnya dengan S/C, faktor yang mempengaruhi CR adalah nutrisi pakan yang diberikan, variasi lingkungan, ketepatan waktu pelaksanaan IB maupun kualitas dan penanganan dari straw yang digunakan. Hal senada juga dinyatakan oleh Ihsan (2010), bahwa kemungkinan yang 
menyebabkan rendahnya CR, yaitu: kualitas semen di tingkat peternak menurun, kondisi akseptor yang tidak baik karena faktor genetik, faktor fisiologis yang disebabkan oleh pakan, suhu, iklim dan manajemen pemeliharaan, deteksi berahi yang tidak tepat karena kelalaian peternak dalam mendeteksi berahi/melaporkan kepada inseminator, dan teknik IB yang dipengaruhi oleh keterampilan inseminator dalam ketepatan waktu IB dan deposisi semen dalam organ reproduksi betina.

\section{Perkembangan Kelembagaan IB di Sumatera Barat}

\section{A. Kabupaten Limapuluh Kota}

Pelayanan IB di Kabupaten Limapuluh Kota telah dilakukan sejak lama, mengingat Kabupaten Limapuluh Kota merupakan sentra pengembangan sapi potong sejak zaman Belanda dengan adanya Induk Taman ternak (ITT) yang sekarang dikenal dengan BPTUHPT Padang Mengatas. Hingga saat ini telah ada 20 Pos IB dan 8 ULIB yang tersebar diseluruh kecamatan.

Berdasarkan data S/C, CR dan cakupan wilayah binaan pada tabel 2, terlihat bahwa Kabupaten Limapuluh Kota sudah bisa dikategorikan kepada Wilayah Tahapan Pelayanan IB Swadaya, namun untuk kriteria jumlah pelayanan IB/tahun 
(dosis), jumlah akseptor (ekor/tahun/inseminator) dan populasi akseptor (\%), Kabupaten Limapuluh Kota masih berstatus Tahap Pengembangan. Disamping itu pelayanan IB masih memanfaatkan sumber dana dari APBN dan APBD meskipun demikian inseminator masih menerima pembayaran dari peternak dengan besaran tertentu.

\section{B. Kabupaten Agam}

Pelayanan IB di Kabupaten Agam telah dilakukan sejak tahun 1974, memiliki 8 Pos IB yaitu Pos IB Lubuk Basung dengan 2 orang inseminator, Pos IB Tiku dengan 1 orang inseminator, Pos IB Matur dengan 8 orang inseminator, Pos IB Sungai Pua dengan 2 orang inseminator, Pos IB Biaro dengan 2 orang inseminator, namun satu orang tidak aktif, Pos IB Malalak memiliki 2 orang inseminator namun keduanya tidak aktif melakukan pelayanan kepada peternak, Pos IB dengan 3 orang inseminator, namun yang aktif hanya 1 orang inseminator, Pos IB Palupuah dengan 4 orang inseminator, namun yang aktif melayani peternak hanya 1 orang saja.

Berdasarkan data CR, jumlah pelayanan IB/tahun (dosis), jumlah akseptor (ekor/tahun/inseminator) dan populasi akseptor (\%) pada tabel 2, Kabupaten Agam masih berstatus Tahap Pengembangan, sedangkan untuk kriteria $\mathrm{S} / \mathrm{C}$ dan 
cakupan wilayah binaan, terlihat bahwa Kabupaten Agam sudah bisa dikategorikan kepada Wilayah Tahapan Pelayanan IB Swadaya. Pelayanan IB masih memanfaatkan sumber dana dari APBN dan APBD meskipun demikian inseminator masih menerima pembayaran dari peternak dengan besaran tertentu dan menurut inseminator PNS yang sempat diwawancarai, dalam pelayanan IB kesempatan lebih banyak diberikan kepada tenaga inseminator Non PNS.

\section{Kabupaten Solok}

Pelayanan IB di Kabupaten Solok telah berlangsung lebih dari 10 tahun. Hingga saat ini (November 2014) telah ada 4 Puskeswan, diantaranya: Wilayah I Singkarak yang memiliki 6 Pos IB dengan 7 orang inseminator, Wilayah II Koto Baru yang memiliki 5 Pos IB dengan 6 orang inseminator, wilayah III Muara Panas memiliki 4 Pos IB dengan 5 orang inseminator, dan Wilayah IV Alahan Panjang yang memiliki 2 Pos IB dengan 4 inseminator, serta 1 SP-IB dengan 2 orang inseminator, sehingga total tenaga inseminator pada Kabupaten Solok berjumlah 22 orang, dimana 11 orang inseminator berstatus PNS, 11 orang lainnya non PNS. 9 orang dari 22 tenaga inseminator tersebut telah mengikuti pelatihan PKB (pemeriksaan kebuntingan), 6 orang diantaranya juga telah 
mengikuti pelatihan ATR (asisten teknis reproduksi), dan 2 orang yang sampai ke tahap ET (Embrio Transfer).

Berdasarkan data S/C, CR dan cakupan wilayah binaan pada tabel 2, terlihat bahwa Kabupaten Solok sudah bisa di kategorikan kepada Wilayah Tahapan Pelayanan IB Swadaya, namun untuk kriteria jumlah pelayanan IB/tahun (dosis), jumlah akseptor (ekor/tahun/inseminator) dan populasi akseptor (\%), Kabupaten Solok masih berstatus Tahap Pengembangan. Disamping itu pelayanan IB masih memanfaatkan sumber dana dari APBN dan APBD meskipun demikian inseminator masih menerima pembayaran dari peternak dengan besaran tertentu.

\section{Kabupaten Pasaman Barat}

Pelayanan IB di Kabupaten Pasaman Barat telah dilakukan lebih dari 10 tahun, salah seorang inseminator senior sudah mengabdi di Pasaman Barat lebih dari 15 tahun. Hingga saat ini telah memiliki 8 Pos IB dan 7 ULIB dengan 15 orang tenaga IB ( 2 orang tidak aktif), 11 orang $(73,3 \%)$ diantaranya merupakan tenaga PKB, 5 orang $(33,3 \%)$ tenaga ATR.

Berdasarkan data S/C, CR dan cakupan wilayah binaan pada tabel 2, terlihat bahwa Kabupaten Pasaman Barat sudah bisa di kategorikan kepada Wilayah Tahapan Pelayanan IB Swadaya, namun untuk kriteria jumlah pelayanan IB/tahun 
(dosis), jumlah akseptor (ekor/tahun/inseminator) dan populasi akseptor (\%), Kabupaten Pasaman Barat masih berstatus Tahap Pengembangan. Disamping itu pelayanan IB masih memanfaatkan sumber dana dari APBN dan APBD meskipun demikian inseminator masih menerima pembayaran dari peternak dengan besaran tertentu sesuai dengan jarak tempuh ke lokasi mengingat peternak yang tersebar luas di Kabupaten Pasaman Barat.

Rendahnya persentase akseptor pada wilayah ini disebabkan karena Kabupaten Pasaman Barat merupakan sentra pengembangan sapi Bali dengan pola intergrasi sapi-sawit yang sistem pemeliharaannya secara semi-intensif sehingga perkawinan berlangsung secara alami.

\section{E. Kabupaten Dharmasraya}

Pelayanan IB di Kabupaten Dharmasraya telah dilakukan lebih dari 10 tahun yang lalu. Hingga saat ini telah ada 8 SP-IB Kecamatan, memiliki 23 orang tenaga IB diantaranya 16 orang $(69,5 \%)$ tenaga PKB, 9 orang $(39,1 \%)$ tenaga ATR serta 3 orang $(13,0 \%)$ tenaga ET.

Berdasarkan data S/C, CR dan cakupan wilayah binaan pada tabel 2, terlihat bahwa Kabupaten Dharmasraya memiliki nilai $\mathrm{S} / \mathrm{C}$ paling rendah dengan $\mathrm{CR}$ tertinggi dibandingkan 5 
kabupaten/kota yang lain, sehingga Kabupaten ini juga sudah bisa di kategorikan kepada Wilayah Tahapan Pelayanan IB Swadaya, namun untuk kriteria jumlah pelayanan IB/tahun (dosis), jumlah akseptor (ekor/tahun/inseminator) dan populasi akseptor (\%), Kabupaten Dharmasraya masih berstatus Tahap Pengembangan. Disamping itu pelayanan IB masih memanfaatkan sumber dana dari APBN dan APBD meskipun demikian inseminator masih menerima pembayaran dari peternak dengan besaran tertentu sesuai dengan jarak tempuh ke lokasi mengingat peternak yang tersebar luas di Kabupaten Dharmasraya.

Sama halnya dengan Kabupaten Pasaman Barat, rendahnya persentase akseptor pada wilayah Kabupaten Dharmasraya disebabkan karena wilayah ini merupakan sentra pengembangan sapi Bali dengan pola intergrasi sapi-sawit yang sistem pemeliharaannya secara semi-intensif sehingga perkawinan berlangsung secara alami.

\section{F. Kota Padang}

Pelayanan IB di Kota Padang telah dilakukan sejak lebih dari 25 tahun yang lalu, hingga saat ini telah ada 6 Pos IB yang tersebar disemua kecamatan dengan 7 orang tenaga inseminator yang juga sudah mengikuti pelatihan PKB. 
Berdasarkan data S/C, CR, cakupan wilayah binaan dan jumlah akseptor (ekor/tahun/inseminator) pada tabel 2, terlihat bahwa Kota Padang sudah bisa di kategorikan kepada Wilayah Tahapan Pelayanan IB Swadaya, namun untuk kriteria jumlah pelayanan IB/tahun (dosis), dan populasi akseptor (\%), Kota Padang masih berstatus Tahap Pengembangan. Disamping itu pelayanan IB masih memanfaatkan sumber dana dari APBN dan APBD meskipun demikian inseminator masih menerima pembayaran dari peternak dengan besaran tertentu.

\section{KESIMPULAN DAN SARAN}

Berdasarkan batasan dan kriteria wilayah tahapan pelayanan IB, maka dapat disimpulkan bahwa Kabupaten Limapuluh Kota, Kabupaten Agam, Kabupaten Solok, Kabupaten Pasaman Barat, Kabupaten Dharmasraya dan Kota Padang masih berstatus Wilayah Tahap Pengembangan walaupun S/C Ratio dan CR sudah termasuk ke wilayah tahap swadaya. 


\section{DAFTAR PUSTAKA}

Adikarta, E. W. 1981. Inseminasi Buatan pada Ternak Sapi dan Kerbau. Jurusan Ilmu Ternak Universitas Gajah Mada, Yogyakarta.

Adell. 1968. Cttle Fertillity and Sterility, $2^{\text {nd }}$ Ed. Printing Little Brown and co, Boston, Toronto.

Afiati, F., Herdis, dan S. Said. 2013. Pembibitan Ternak dengan Inseminasi Buatan. Penebar Swadaya. Jakarta

Dikman, D.M., L. Affandy, dan D. Ratnawati. 2010. Petunjuk Teknis Perbaikan Teknologi Reproduksi Sapi Potong Induk. Loka Penelitian Sapi Potong, Grati-Pasuruan: 1-13.

Ihsan, M.N. 2010. Indek Fertilitas Sapi PO dan Persilangannya dengan Limousin. Jurnal Ternak Tropika, 11 (2): 82-87

Partodihadjo, S. 1995. Ilmu Reproduksi Hewan. Cetakan kedua. PT. Mutiara Sumber Wydia, Jakarta

Rasad, S.D. 2009. Evaluasi Penampilan Reproduksi Sapi Perah (Studi Kasus di Perusahaan Peternakan Sapi Perah KUD Sinarjaya). Jurnal Agripet, 9 (1) : 43-49.

Sahili. 1993. Pengaruh Pengencer Susu pada Semen Epididimis dan Waktu Penyimpanannya terhadap Kualitas dan Fertilitas. Jurnal Peternakan dan Lingkungan No. 13 : 7076 
Salisbury, G. W. dan N. L. Van Demark. 1985. Fisiologi

Reproduksi dan Inseminasi Buatan pada Sapi.

Terjemahan oleh R. Djanuar. Gajah Mada University

Press, Yogyakarta.

Sastroamidjojo, M. S. dan Soeradji. 1990. Ilmu Peternakan

Umum. CV. Yasaguna, Jakarta.

Soenarjo. 1988. Fertilitas dan Infertilitas Pada Sapi Tropis. CV Baru. Jakarta

Susilawati, T. 2011. Tingkat Keberhasilan Inseminasi Buatan dengan Kualitas dan Deposisi Semen yang Berbeda Pada Sapi Peranakan Ongole. J.Ternak Tropika, 12 (2): 15-24.

Toelihere, M. R. 1985. Inseminasi Buatan pada Ternak. Angkasa, Bandung. 